\title{
Central Bank Policy in Times of Turbulence on Financial Markets
}

\author{
Mikhail Zharikov
}

Doctor of Economics, World Economy and World Finance Department, Professor; Financial University under the Government of the Russian Federation, Moscow, Russia michaelzharikoff@gmail.com

http://orcid.org/0000-0002-2162-5056

\section{Abstract}

This article is devoted to a central bank's response to a financial crisis based on a case study of the US Federal Reserve's handling of the financial crisis in 2008-2010. This article will also be focusing on the intense phase of the financial crisis. It is focusing primarily on the lender of last resort function of a central bank. The article concludes with the most significant issues about the aftermath and the recovery, as well as lessons to deal with financial failure during the coronavirus and its aftermath.

Keywords: central bank policy; lender of last resort function; financial crisis; coronavirus; too big to fail; Volcker rule; regulatory framework; securitisation; credit ratings

JEL Classification: F37

(c) Mikhail Zharikov, 2020

\section{The Background of the Federal Reserve's Response to the Financial Crisis}

As soon as lockdowns have hit the financial markets, meltdowns of major economies and enterprises across the globe caused by the pandemic in early 2020, policymakers have tried to pursue different kinds of policies. The article finds it best to turn to the experience in dealing with financial crises based on lessons of the Federal Reserve from the previous financial crunch of 2008.

A central bank has two main responsibilities: financial stability and economic stability. For financial stability, the main tool that central banks have is the lender of last resort powers by providing short-term liquidity to financial institutions replacing lost funding. For economic stability, the principle tool is monetary policy. That involves adjusting the level of short-term interest rates.

The vulnerabilities in the financial system transformed the decline in housing prices and led to a very severe crisis. Private sector vulnerabilities included excessive debt. A bank's inability to monitor its risks and excessive reli- ance on short-term funding makes it vulnerable to a run. There was also increased use of exotic financial instruments like credit default swaps and others that concentrated risk in particular companies and particular markets (Avdokushin \& Kovalenko, 2012).

The public sector had its vulnerabilities, including gaps in the regulatory structure, with important firms and markets that did not have adequate oversight. Although there was adequate oversight, it existed at least basically in law. However, sometimes the supervisors and regulators did not pay enough attention to forcing banks to do better monitoring and managing their risks. Finally, a significant gap in a central bank's policy was that there was not enough attention paid to the stability of the financial system taken as a whole.

Another crucial public sector vulnerability involved government-sponsored enterprises (GSEs) Fannie Mae and Freddie Mac. They are private corporations. They have shareholders in their board, but Congress established them in support of the housing industry. Fannie and Freddie do not make mortgages. They are the middleman between the originator of the mort- 
gage and the ultimate holder of the mortgage. For example, a bank makes a mortgage loan and then sells it to Fannie or Freddie. They will, in turn, take all the mortgages that they collect, put them together into mortgage-backed securities (MBS). A mortgage-backed security is a security that is a combination of hundreds of thousands of underlying mortgages. Then they sell that to the investors. That is a process called securitisation. Fannie and Freddie pioneered this basic approach to getting funding from mortgages (Bernanke, 2015).

In particular, when the GSEs sell their mortgage-backed securities, they provide guarantees against credit loss. Fannie and Freddie were permitted to operate with adequate capital. While many aspects of the financial crisis were not well anticipated, this one was. The Fed said that Fannie and Freddie just did not have enough capital and that they were, in fact, a danger to the stability of the financial system.

What made the situation even somewhat worse was that Fannie and Freddie besides selling these mortgage-backed securities to investors, also purchased on their account large amounts of mortgage-backed securities both their own and some that were issued by the private sector. They made profits from holding those mortgages.

An important trigger of the crisis was that this was not just a house-price boom and bust, but it was the mortgage products and practices that went along with the house price movements that were particularly damaging. There were a lot of exotic mortgages by which economists mean non-standard and standard mortgages, thirty-year, prime, fixed-rate mortgages, etc. There were all kinds of mortgages being offered and often to people with weaker credit and poor credit ratings (Binder, 2013).

One feature that many of these mortgages had was that for them to be repaid, one had to have ongoing increases in house prices. So, for example, someone might be a mortgage borrower who would buy an adjustable-rate mortgage or ARM where the initial interest rate was, say, 1 per cent which meant that one could afford the payment for the first year, too. After two years the mortgage rate might go up to 3 per cent and after four years 5 per cent and then higher and higher. So, in order to avoid that, the borrower had to at some point refinance into a more standard mortgage. And as long as house prices were going up, creating equity for homeowners, it was possible to do that refinance (Burlačkov, 2012).

But once home prices stopped rising [and by 2006 they were already declining quite sharply] borrowers, rather than having building equity, found themselves underwater. They could not refinance, and they found themselves stuck with these increasing payments on their mortgages. There are, of course, some examples of bad mortgage practices. There are so many of them that it is impossible to go through all of them. But they all have the same characteristics. Most of these mortgages had the feature that they reduced monthly payments at least early in the mortgage but allowed mortgage payments to rise overtime.

The other aspect of lousy mortgage practices like no-doc loans, for example, was that there was minimal underwriting which means very little analysis to make sure that the borrower was creditworthy and was able to make the payments on the mortgage.

Mortgage companies, banks, savings and loans enterprises and a variety of other different kinds of institutions made these mortgages. Some of them were kept on the balance sheet of the mortgage originator, but many or most of these exotic or sub-prime mortgages were packaged in securities and sold off into the market.

Some of the securities that were created were very complex and very hard to understand. An example would be a collateralised debt $\mathbf{o b}$ ligation (CDO). It would often be security to combine mortgages and other kinds of types of debt in one package. A mortgage company would sell to one investor the safest part of the security, and to another investor the riskiest part of the security. One reason that many investors were willing to buy these securities was that they had the comfort of the rating agencies whose job it is to rate the quality of warrants and other securities, giving $A A A$ ratings to many of these securities, essentially saying that they were very safe. And therefore, one did not have to worry about the credit risk of these securities (Butorina, 2011).

Many of these securities were sold to investors including pension funds, insurance 
companies and foreign banks, even, in some cases, wealthy individuals, but also the financial institutions that either made these loans or created these securities and often retained some of them as well.

For example, sometimes they would create an accounting fiction or off-balance-sheet vehicle which would hold these securities and finance itself by cheap short-term funding like commercial paper. Some of these securities went to investors. Some of them stayed with the financial institutions themselves.

Besides, there were companies like AIG that were selling insurance. They were using various kinds of credit derivatives to basically to say that a borrower had to pay them a premium. If the mortgages in the borrower's mortgagebacked security went bad, they would make it good. And that was AAA-rated.

Of course, these practices made the underlying securities no better. But what they also did was they created a situation where risks could be spread throughout the system. Sub-prime mortgage securitisation worked very peculiarly. There were low quality-mortgages, which meant one might have a mortgage company or a thrift company making the loans.

The thrift company or the mortgage company does not care too much about the quality of the loan because they are going to sell it anyway. So, they take the mortgages, and they sell them to large financial firms who take those mortgages, and maybe other securities as well, combine them into security which is essentially an amalgamation of all the underlying mortgages and other securities.

The financial firm that created the security might negotiate with the credit rating agency to say what one had to do to get AAA rating, and there would be negotiations and discussions. In the end, the security will be rated AAA. The financial firm will then take the security, could carry it up in different ways or just sell it as it is, sells it to investors like a pension fund or some other type of investor. But also, financial firms kept many of these securities on their books or in related investment vehicles. And finally, there were credit insurers like AIG and other mortgage insurance companies that for a fee provided insurance in case the underlying mortgages went bad (Goldberg \& Cédric, 2008).

\section{Central Bank Policy Lessons}

The crisis of 2008-2010 was basically a classical financial panic but in a different institutional setting: not in the bank setting but in a broader financial setting. So, in particular, as house prices fell in 2006 and 2007, people who borrowed on a sub-prime mortgage were not able to make the payments. It was increasingly evident that more and more were going to be delinquent or default, and that was going to impose losses on the financial firms, the investment vehicles they created and also credit insurers like AIG.

Unfortunately, the securities were so complex, and the monitoring of the financial firms of their risks was not sufficiently strong that it was not just the losses. A very striking fact is that if one took all the sub-prime mortgages in the United States and put them all together and assume they are all worthless, the total losses to the financial system would be about the size of one rotten egg at the stock market. But the problem was they were distributed throughout different securities and different places, and nobody really knew where they were and who was going to bear the losses.

So, there was a lot of uncertainty in the financial markets. As a result, wherever one had short-term funding, whether it was commercial paper or other short-term types of funding, banks had all kinds of funding that were not depositinsured - so-called wholesale funding - and it came from investors and other financial firms (Griesgraber, 2009).

Whenever there was a doubt about a firm, just like in a standard bank run, the investors, the lenders and the counterparties would pull back their money quickly for the same reason that a depositor would pull back their money out of a bank that was thought to be having trouble. So, there was a whole series of runs which generally had tremendous pressures on key financial firms as they lost their funding and were forced to sell their assets quickly. And many important financial markets were badly disrupted.

In the depression of the 1930s, there were thousands of bank failures. Almost all of the banks that failed in the 1930s, at least in the United States, were small banks. And some larger banks failed in Europe. The difference in 2008, many small banks failed in the United States, 
but there were also intense pressures on quite a few of the largest financial institutions in the United States (Jordà \& Schularick, Taylor, 2011).

There are cases in a shortlist of some of the firms that came under intense pressure. Bear Stearns, which is a broker-dealer, came under intense pressure in the short-term funding market in March of 2008. It was sold to J.P. Morgan with Fed's assistance in March 2008. Things calmed down a bit after that, and over the summer, there was some hope that the financial crisis would moderate. But then in the late summer things really began to pick up. On September $7^{\text {th }} 2008$, Fannie and Freddie were clearly insolvent. They did not have enough capital to pay the losses on their mortgage guarantees. The Federal Reserve worked with the Fannie and Freddie's regulator and with the Treasury to determine the size of the short-fall. Over the weekend, the Treasury with the Fed's assistance came in and took those firms and put them into a form of limited bankruptcy called conservatorship.

At the same time, the Treasury got authorisation from Congress to guarantee all of the Fannie and Freddie obligations. If one held a Fannie or Freddie mortgage-backed security, the company itself was now on a partial bankruptcy. There was an enormous intensification of the crisis because investors all over the world held hundreds of billions of those securities literally. Famously, in mid-September 2008, Lehman Brothers, a broker-dealer, had severe losses. It came under tremendous pressure. It could not find either anybody to buy it or to provide capital for it. On September $15^{\text {th }} 2008$ it filed for bankruptcy. On the same day, Merrill Lynch, another big broker-dealer, was acquired by the Bank of America, saving the firm from potential collapse.

On September $16^{\text {th }} 2008$, AIG, which was the largest multi-dimensional insurance company in the world which had been selling the credit insurance, came under enormous attack from the people demanding cash either through margin requirements or through short-term funding. The Fed provided emergency liquidity assistance for AIG and prevented the firm from failing.

Washington Mutual was one of the biggest thrift companies, a big provider of sub-prime mortgages, was closed by regulators later in September 2008, after parts of the company were taken off. J.P. Morgan acquired this company as well.

On October $3^{\text {rd }} 2008$, Wachovia, one of the five biggest banks in the United States, came under severe pressure. It was acquired by Wells Fargo, another large mortgage provider. All of these firms were among the top ten or fifteen financial firms in the United States. Similar things were happening in Europe. It was not a situation where only small firms were being affected. Here were the biggest, most complex international and financial institutions at the brink of failure (Kadayan, 2014).

Lessons from the crisis going back are two. First, in a financial panic, the central bank has to lend freely according to the Bagehot's rules to hold runs and to try to stabilise the financial system. The second lesson of the crisis - the Fed should do enough to prevent deflation and contraction of the money supply. It needs to have an accommodative monetary policy to help the economy avoid a deep depression.

Keeping in mind those lessons, the Federal Reserve and the Federal government did take vigorous actions to stop the financial panic, work with other agencies and work internationally with foreign central banks and governments (Kasekende, Brixova \& Ndikumana, 2010).

One aspect of the crisis, which does not get quite enough attention, is the fact that it really was, first of all, a global crisis. In particular, Europe, as well as the US, were suffering very severely from the crisis. It was also an imposing example of international cooperation like G7 or G20. The G7 are the seven largest industrial countries. The central bank governors and the finance ministers of those seven countries came and met in Washington. They were going to work together to stop this crisis which was threatening the global financial system. Finally, they came up with a statement that was written from scratch, based actually on some Fed proposals and was circulated, and there were several principles and statements involved in that (Kaufman, 2001).

Among those were first that the $\mathrm{G} 7$ countries were going to work together to prevent the failure of any more systemically important financial institutions. It was after Lehman Brothers had failed. They were going to make sure that banks and other financial institutions had ac- 
cess to funding from central banks and capital from governments. They were going to work to restore depositor confidence and investor confidence. And then they were to cooperate as much as possible to normalise credit markets (Lane \& Milesi-Ferretti, 2011).

It was a global agreement, and subsequent to this agreement just in the following week, the UK was the first to announce a comprehensive programme to stabilise its banking system. The US announced significant steps to put capital into the country's banks, and so on. So, a lot really happened in just the next couple of days after this meeting.

Just to show that this cooperation worked, the following should be said about the interest rate charged on loans between banks. It is the inter-bank interest rate. So, if Bank A lends to Bank B overnight, this is the interest rate that was charged. Typically, the overnight interest rate between banks is extremely low, way less than 1 per cent, because banks need someplace to park their money overnight, and they have a lot of confidence that it is safe to lend to another bank overnight. As one can see starting in 2007, banks lost trust in each other, and that is shown by the increase in the rates they charged to each other to make loans.

What was indicative of that was that suddenly there was no trust whatsoever even between the largest financial institutions because nobody knew who was going to be next, who was going to fail and who was going to come under funding pressure. After the international announcements, within a few days, one began to see a reduction in the pressure, and there was an enormous improvement in the funding pressures in the banking system (Schindler, 2009).

The Fed played an important role, however, in providing liquidity and making sure that the panic was controlled. The Federal Reserve has a facility called the discount window, which it uses routinely to provide short-term funding to banks. Maybe a bank just finds itself short off funding at the end of the day. It wants to borrow overnight. It has collateral with the Fed. Based on that collateral, it can borrow overnight at what is called the discount rate, which is the interest rate that the Fed charges. No extraordinary steps were needed to lend to banks. The Fed always lends to banks. The Fed did make some modifications in order to reassure the banks about the availability of credit. To get more liquidity into this system, they extended the maturity of this kind of window loans which were enormous overnight loans. The Fed made them longer term. The Fed had auctions of these discount window funds where firms bid on how much they would pay. The idea there was by having a fixed amount that they were auctioning. They would at least assure themselves that they got a lot of cash in the system. Anyway, the point here is that the discount window, which is the Fed's usual lender-of-last-resort facility, lending to banks was opportunitive, and they used aggressively to make sure that banks had access to cash to try to calm the panic (Wade, 2008).

The Fed also had to go beyond the discount window. It had to create a whole bunch of other programmes. These special liquidity and credit facilities allowed them to make loans to other kinds of financial institutions, again on the Bagehot's principle that providing liquidity to firms that are suffering from the loss of funding is the best way to calm the panic. All these loans were secured by collateral. They were not taking chances with taxpayer money. The cash was going not just to banks, but more broadly to the system. The purpose of this was to enhance the stability of the financial system and get credit flows moving again. And just to emphasise: this is the traditional lender-oflast-resort function of central banks that have been around for hundreds of years. What was different was that it took place in a different institutional context than just the traditional banking context.

There are some of the institutions and markets that the Fed addressed through special programmes. Banks, of course, were covered by the discount window. Still, another class of financial institutions - broker-dealers, which are financial firms that deal in securities and derivatives, were also facing severe problems. It included Bear Stearns and Lehman Brothers, Merrill Lynch, Goldman Sachs, Morgan Stanley and others, and the Fed provided cash or less short-term lending to those firms on a collateralised basis as well.

Finally, in the modern economy, the current financial system has a lot of the funding which 
one gets for not just mortgages but auto loans and credit cards. All three kinds of consumer credit are funded through the securitisation process. It means that a bank might take all of its credit card receivables, bundle them together to security and then sell them in the market to investors in much the same way that mortgages were sold. It is called the asset-backed securities market.

The asset-backed securities market dried up during the crisis, and the Fed created some new liquidity programmes to help it. These types of lending required the Fed to involve emergency authorities. There is a clause in the Federal Reserve Act 13-3 which says that under unusual and exit circumstance, basically an emergency, the Fed can lend to other types of entities, other than just banks. The Fed had not used this authority since the 1930s. In this particular case, with all these other problems emerging in different institutions and different markets, the Fed invoked this authority. It used it to help stabilise a variety of different markets.

For example, money-market funds are basically investment funds in which one can buy shares, and money-market funds take someone's money and invest it in short-term liquid assets. Money-market funds historically have almost always maintained a one-dollar share-price. So, they are very much like a bank actually. Institutional investors like pension funds frequently use them.

A pension fund with 30 million dollars in cash probably would not put that into a bank because that much money is not insured. There are limits to how much deposit insurance covered. What a pension fund might do instead of putting the cash in a bank, it will be to put the money into a money market fund which promises one dollar for each dollar put in plus a little bit of interest on top and invest in very short-term safe liquid-type assets. So, it is a pretty good way to manage one's cash if one is an institutional investor of some kind ( $\mathrm{Yu}$, 2014).

Many investors were putting their money into money-market funds. Money market shares are not insured. They do not have deposit insurance, but the investors who put their money into a money market fund expect that they can take their money out at any time dollar for dollar. So, they treat it like a bank account basically.

\section{Acute Measures to be Taken in a Financial Crisis}

The money-market funds, in turn, have to invest in something, and they tend to invest in safe short-term assets like commercial paper. Commercial paper is a short-term debt instrument issued typically by corporations. Shortterm is ninety days or less, typically. A nonfinancial corporation might issue commercial paper to allow it to manage its cash flows. It might need some short-term money to meet its payroll to cover its inventories.

Ordinary manufacturing companies like GM or Caterpillar would issue a commercial paper to get cash to manage their daily operations. Financial corporations, including banks, would also issue commercial paper to get funds that they can then use to manage their liquidity positions, and they can use again to make loans to the private economy.

The investors were investing their assets to cash in a money-market fund. The money market fund buys commercial paper, which is a funding source for both non-financial businesses like manufacturers and for financial companies who would lend it on to other borrowers.

Lehman Brothers created a huge shock wave because Lehman Brothers was an investment bank. It was a global financial services firm. It was not a bank. So, it was not overseen by the Fed. It was an investment company. It held lots of securities. It did a lot of business in the securities markets. It could not take deposits, not being a bank. Instead, it funded itself in shortterm funding markets, including the commercial paper market.

Lehman invested heavily in mortgage-related securities and also in commercial real estate during the 2000s. As house prices fell and delinquencies on mortgages rose, Lehman's financial position got worse. They were again using lots of money in the commercial real estate. Lehman was becoming insolvent. It was losing money, all of its investments, and it was coming under a lot of pressure. Indeed, as Lehman's creditors lost confidence, they started withdrawing funding from Lehman.

For example, investors refused to roll over Lehman's commercial paper. And other business partners said they were not going to do business if Lehman did not do anymore, because due to 
a failure the latter may not be here next week. Lehman tried with the Federal Reserve and the Treasury`s help to either find somebody willing to put more capital into the firm or to acquire the firm. It was unable to do that. So, on September $15^{\text {th }} 2008$, as was already mentioned it filed for bankruptcy. It was an enormous shock that affected the whole global financial system.

This time in 2020, it was the coronavirus. In particular, one of the many implications of the failure was again in the money-market funds. There was one particular fairly large moneymarket fund that held among its other assets commercial paper issued by Lehman. When Lehman failed, that commercial paper was either worthless or at least entirely illiquid for a long time. Suddenly this money-market fund could no longer pay off its depositors at a dollar per share. It did not, and it lost money.

The Fed and the Treasury responded very quickly to the situation. The Treasury provided a temporary guarantee which said that they guarantee that a person gets his/her money back if he/she just do not pull it out right now. The Fed created a back-stop liquidity programme under which they lent money to banks who in turn used that money to buy some of the assets of the money-market funds. That gave the money. There were the money outflows from the moneymarket funds. It is a two-trillion-dollar industry. Following that announcement for about two days there about a hundred billion dollars a day was flowing out of these funds. Within two days the Treasury announced a guarantee programme. The Fed came to support the liquidity of these funds. The runs ended pretty quickly. It is an absolutely classic bank run and a traditional response, i.e. providing liquidity to help the institution being run, provide the cash to its investors, providing the guarantees, and that successfully ending the run.

But that was not the end of the story, because the money-market funds were also holding the commercial paper. As they began to face runs, they, in turn, began to dump commercial paper as quickly as they could. As a result, the commercial paper market went into shock. It is a really nice example of how financial crises can spread in all different directions.

Furthermore, as the money-market funds withdrew from the commercial paper market, there was a sharp increase in the rate in the commercial-paper market. Lenders ran willingly to lend from more than maybe one day to commercial-paper borrowers, which in turn affected the ability of those companies to function and the ability of those financial institutions to fund themselves.

The Federal Reserve was responding in a way that Bagehot would have had his respond and established special programmes. Basically, the Fed stood as a back-stop lender. The Fed said that the banks should make their loans to these companies, and the Fed would be there right to back-stop the banks if there was a problem rolling over these funds. And that restored confidence in the commercial-paper market.

The Fed was working with these critical markets and providing broad-based liquidity to financial institutions to try to bring the panic under control. But the Fed and the Treasury also got involved in trying to address problems with some individual critical institutions. In March of 2008, as was mentioned before, a Fed loan facilitated the take-over of Bear Stearns by J.P. Morgan Chase avoiding failure of that firm. The reason the Fed undertook that action was first that at the time the financial markets were quite stressed, and the Fed was fearful that the collapse of Bear Stearns would significantly add to that stress and perhaps set off a full-fledged financial panic.

Moreover, it was the Fed's judgement at least that Bear Stearns was solvent, at least J.P. Morgan thought so. They were willing to buy the firm, and they guaranteed its obligations so that by lending to Bear Stearns the Fed was consistent with the proposition that it should be making loans that were likely to be paid back. And the Fed also felt that it was well secured in making the loan that it did.

In a second example, in October of 2008, AIG was very close to failure. It again was the largest insurance company, perhaps among the largest in the world. Let us just discuss a little bit about that case.

AIG was a complicated company. It was, on the one hand, a multinational financial services company with many constituent parts, including several insurance companies and global insurance companies. But it had a part of the company that was called AIG Financial Products that was 
involved in all kinds of exotic derivatives and other types of financial activities including, as was mentioned before, the credit insurance that it was selling to the owners of mortgage-backed securities. So, when the mortgage-backed securities started going wrong, it became evident that the AIG was in big trouble. And its counterparties began demanding cash or refusing to fund AIG.

AIG was coming under tremendous pressure. The failure of AIG and the Fed's estimation would have been the end. It was interacting with so many different firms. It was so interconnected with both the US and the European financial systems and global banks that the Fed was quite concerned that if AIG went bankrupt, that it would not be able to control the crisis any further.

Fortunately, from the perspective of lender-oflast-resort theory, AIG was taking a lot of losses in its financial products 'division. But underlying those losses, that was the world's largest insurance company. So, it had lots of perfectly good assets, and as a result, it had collateral which it could offer to the Fed to allow them to make a loan to provide the liquidity it needed to stay afloat.

And so, to prevent the collapse of AIG, the Fed used AIG assets as collateral and loaned AIG 85 billion dollars, obviously a relatively severe amount of money. Later the Treasury provided additional assistance to keep AIG afloat. And again, it was highly controversial. It was both, the Fed thought, legitimate in terms of lender-oflast-resort theory because it was a collateralised loan. The Fed is not fully paid, in this case. And, secondly, because it was a critical element in the global financial system.

Over time, as was said before, AIG has stabilised. It has repaid the Fed with interest. The Treasury still owns a majority share of its stock, but AIG has been paying back the Treasury as well. It has been in the process of doing that.

The Fed likes to emphasise that what they had to do with Bear Stearns and AIG is obviously not a recipe for future crisis management. First of all, it was a very difficult and, in many ways, the distasteful intervention that the Fed had to do on the grounds of their need to do to prevent the system from collapsing. But clearly, it is something fundamentally wrong with a system in which some companies are 'too big to fail'. If a company is so big that it knows it is going to be bailed out, even putting aside the fairness of that, it is not at all fair to other companies, but even beyond that obviously, they have an incentive to take big risks. They will say they will take big risks, heads they win, tails they lose.

If the risks pay off, then they will make plenty of money. And if they do not pay off, the government will save them. That is too big to fail, and that is a situation which one cannot tolerate.

So, the problem the Fed had in September of 2008 was that it really did not have any tool, or legal tools and policy tools, that allowed it to let Lehman Brothers and AIG and these other firms go bankrupt in a way so that it had not had incredible damage or created astonishing damage on the rest of the system.

Therefore, the Fed chose the lesser of the two evils and prevented AIG from failing. But that being said, going forward the Fed wanted to be sure that this never happens again. It needed to be sure that the system has changed so that if a large systemically critical firm like AIG comes under this kind of pressure in the future that there will be a safe way not to let it fail so that it can fail. The consequences of its mistakes can be borne by its management, shareholders, and creditors. But in doing so, it does not bring down the whole financial system, and the following step it is going to make is about the progress the Fed made collectively in instituting a system that will, as the Fed hopes, eventually at least, end too big to fail.

Finally, a couple of words about the consequences of the crisis should be said. The Fed did stop the meltdown. It avoided what would have been a collapse of the global financial system. That was obviously a good thing. But to give a sense one thing that the Federal Reserve was always sure of was that the collapse of some of these big financial firms were going to have very serious collateral consequences. Some people are arguing even as late as September of 2008, why just not let the firms collapse, because the system can take care of it. The US has a bankruptcy code. Why not let them fail? And the Fed never thought that that was a good option.

Remarkably, the whole system had collapsed, they would have had extraordinarily serious consequences, as it was even though they prevented the total meltdown. There was still evident, as is known, a severe collateral 
impact on not just the US economy but the global economy as well.

So, following the crisis, though the crisis was brought under control, the US economy, and much of the global economy, went into a sharp recession. In the United States, the GDP fell by more than 5 per cent, which is a remarkably deep recession. There are some other statistics: eight and a half per cent of people lost their jobs. And unemployment rose to $10 \%$. So, it was a very consequential impact.

And as was said before, this was not just the US situation. The US recession was, in fact, an average recession. There were many countries around the world with worse declines, particularly those who depended upon international trade. It was a global slowdown. And as all of this was happening, fears of a great depression, or a repetition of the 1930s depression, were genuine.

Nevertheless, the Great Depression was much worse than the recent recession. And the Fed thinks the view is increasingly gaining acceptance that without the forceful policy response that stabilised the financial system in 2008 and early 2009 , the world could have had a much worse outcome in the economy.

\section{Concluding Remarks}

There are a couple of indicators just to close the discussion. The pretty striking thing is that for the first 15 or 16 months in 2008 stock prices in the United States behaved pretty much in this crisis as they did in 1929 and 1930 . But about 15 or 16 months into the recent crisis, which would have placed it in early 2009, about the time when the financial crisis was stabilising, look what happened. In the Depression Era, the stock prices kept falling. And as was already mentioned, in the end, stock prices lost 85 per cent of their value.

In the United States, by contrast, stock prices recovered and began a long recovery, and now they more than doubled where they were three years ago.

One can see in this case that the fall in industrial production was not as quiet as severe and incredibly as fast as in the Depression. But one gets the same basic phenomenon that about 15 or 16 months into the episode, about the time that the financial crisis was brought under control, industrial production bottomed out and began a period of steady recovery. In contrast, in the Depression, the collapse continued for several more years.

So, that is a very rapid overview of the crisis of 2008-2010. The article went more profound into how the monetary policy responded to the recession. Why has the recovery been relatively sluggish? What has happened to financial regulation to try to make sure this never happens again? And what lessons has the Fed taken from this experience?

The article mentioned the increased insurance of exotic securities and sub-prime mortgages. Why are these financial institutions willing to lend such mortgages and bear so much risk to even poker borrowers? And if they are forcing a decrease in prices on the housing market, why they do the same thing? There were a couple of reasons for that. One reason was simply the fact that firms were probably too confident about house-price increases, and said that house prices were likely to keep rising. In a world in which house prices are rising, these are not such bad products altogether, because people can afford to pay for a year, but then they can refinance this something more stable. And this might be a way to get people in the housing, but of course, the risk was that house prices would not keep rising, and of course, that is ultimately what happened.

The other aspect of this was that the demand for securitised products grew very substantially during this period. In part, there was a great international demand from Europe and Asia for high-quality assets. And the ever-clever US financial firms figured out that they could take a variety of different kinds of underlying credits, whether it be sub-prime mortgages or whatever. And through the miracles of financial engineering, they could create from that at least some securities that would be high-quality and would be rated AAA, and which they could then sell abroad to other investors.

Unfortunately, that sometimes left them with the remaining bad pieces which they kept or sold to some other financial firms. So, there were trends in the financial markets, including overconfidence about their ability to manage those risks, a belief that house prices would probably keep rising, a sense that they could, even if they made those mortgages, then sell 
them off to somebody else, and that that other person or another investor would be willing to acquire them. There was a big demand for quote 'safe assets'.

For all these reasons, it was actually a very profitable activity. But it lasted only when the house prices began to fall did it becomes a big loser.

The article was also talking about the major things the Fed had to do to figure out how to get liquidity flowing again in the market, and it reminds the Volcker Rule. As can be understood, the Volcker Rule, of course, bans perpetrating by financial banks. Still, there is also this spacious area for principle trade which is very important for money-makers to create markets and find liquidity. So, what does the Fed think about that? Does not that seem counter-intuitive?

The Volcker Rule is a part of the Dodd-Frank Financial Regulatory Reform, and which the Fed and other agencies are tasked with implementing. The purpose of the Volcker Rule is to reduce the risk of financial institutions by preventing banks and their affiliates from doing quote 'proprietary trading', which means that banks should do their short-term trading on their own account so that in the future they will be prevented from taking those kinds of risks.

The law recognises that there are legitimate exceptions for why banks might want to acquire short-term securities, and those include, for example, hedging against risk. Still, one particular exception is to make markets serve as the intermediaries who buy and sell to create liquidity for a specific market. And that is exempted from the Volcker Rule, and one of the challenges of implementing this rule is trying to figure out how to work out a set of standards that allows the so-called exempted or legitimate activities like market-making and hedging while ruling out the proprietary trading. And that is obviously very difficult.

The Fed is still working on that. They put out a rule where they have got thousands of comments. They are looking at that and trying to figure out how best to do that. But the point the question raised is that liquidity in markets is essential. During the crisis, it was a much worse problem than just a little bit of lack of trading volume. There were big financial institutions unable to fund themselves, unable to find the funding to support their asset positions, the assets that they held, which left them with one of two possibilities either defaulting because they did not have enough funding or the fact that many of them took which was the sort selling off assets as quickly as possible, which in turn spread to panic because if there is a huge sellers' market for, say, commercial real estate bonds, that is going to drive prices very sharply. Then anybody else who was holding those bonds finds their position being eroded, and that created pressure on them.

The Fed did not officially use the word contagion in its discussion. Contagion, just as in an illness context, is the spreading of panic and the spreading of fear from one market or from one institution to another. And contagion was a major problem in many waves of financial panic, but certainly in this one too. And that was one of the mechanisms that led the funding pressures to jump from firm to firm and create such a broad-based problem.

There is a question specifically about global collaboration during the financial crisis. The article talked about G7. Specifically, multinational corporations began to go beyond the brink of failure. What pressures came from the international community? One decision to say bail-out AIG was being debated.

There were not any real pressures. Everything was happening too fast. In fact, one area where collaboration was not as good as the Fed would like to was exactly dealing with some of these multinational firms. For example, there were problems between the UK and the US over the Lehman Brothers' failure and inconsistencies which caused problems for some of the creditors of Lehman. So, one of the things that the Fed is trying to do under the Dodd-Frank Financial Reform Legislation which includes, as was mentioned before, provisions for safely allowing large financial firms to fail.

But one of the complexities there is that many of the firms that this would be applied to are multinational firms. It does not mean to say just two or three countries. It may involve dozens of countries. And so, collaboration with other countries in figuring out how they would work together to help a large multinational firm fail as safely as possible was part of what was going on as they worked internationally. During 
the crisis, they tried to cooperate in a mostly $\boldsymbol{a d}$ hoc way.i.e. the Fed was in touch with regulators in the UK and elsewhere. But given the time frames and the lack of preparation, they did not do as much as they would be able to do with a lot more lead time.

So, that was a weakness of international collaboration. For the most part, though, countries cooperated in dealing with the financial institutions that were based in their own countries. AIG was an American company. And the Fed dealt with that, whereas a company like Dexia, which was a European company, was dealt with by the Europeans.

Also, there was a lot of cooperation between central banks, and there were a lot of European banks that used dollars that needed dollar funding as opposed to euro funding. They used dollar funding because they held dollar assets. They made dollar loans. They made loans to support trade, which is often done in dollars, so, they needed dollars.

The European Central Bank cannot provide dollars. So, what the Fed did was what was called a swap, where the Fed gave the European Central Bank dollars. And the European Central Bank delivered the Fed euros. They took the dollars, the Fed gave them and lent them under their own reconnaissance to European banks taking off the dollar-funding pressure and easing dollar-funding tensions around the world.

Those swaps which are still in existence now because of the recent issues with the coronavirus in the world were an important example of collaboration.

Also, right as this crisis was intensifying, the Federal Reserve and five other central banks all announced interest rate cuts on the same day. So, they coordinated even their monetary policy. They did their best to coordinate. There were some areas where a lot more preparation was needed, like working on multinational firms. And the Fed is still working on those things cooperatively today.

What are the off-balance-sheet vehicles that were being used, and why they were allowed to be used? And why were they allowed to keep much sham information on their books?

It has to do with accounting rules, basically. Someone creates this particular vehicle, and the bank might have a substantial interest in that vehicle. It might, for example, have partial ownership. It might have some promises to provide credit support if it goes wrong, or liquidity support if it needs cash. But it does not have to under those rules that existed in those times if the amount of control that the bank had on this off-balance-sheet vehicle was sufficiently limited. Then according to the accounting rules, it could treat it as a separate organisation, so to speak, not part of its balance sheet. And that allowed the banks to get away with somewhat less capital, for example, than they would have had to carry if they had all these assets on their balance sheet.

One of the many promising developments since the crisis is that these rules have been reworked, and many of the off-balance-sheet vehicles that existed before the crisis would no longer be allowed. They would have to be consolidated, which means they would have to be brought back on to the balance sheet, made part of the bank's balance sheet, have appropriate capital and so on. So, those practices are not entirely gone, but the accounting rules have considerably toughened up. The situation and the circumstances under which one can put something off the balance sheet into a separate investment vehicle are quite acute.

The article mentioned several large firms that came under pressure in 2008 and also the Fed's doctrine of too big to fail. The question is where one can draw the line between bailing out a bank and allowing it to fail? Is it arbitrarily, or is there some sort of methodology that goes behind?

First of all, the Fed would like to resist that word doctrine a little bit. These firms proved to be too big to fail in the context of the global financial crisis. There was a judgement the Fed made at the time based on their size, their complexity and their interconnectedness. It was not something that they ever thought it was a good thing. And again, one of the main goals of the financial reform is to get rid of it, because it is bad for the system and it is bad for the firms. Also, it is unfair in many ways. And it will be a great accomplishment to get rid of too big to fail.

So, it is not something that the Fed advocates or supports in any way. And they were just forced into a situation where they had to choose the least bad of a number of different options. 
During the crisis, the Fed had basically to make judgements on a case-by-case basis, and they were trying to be as conservative as possible. In the case, indeed, of AIG, there was really not much doubt in the Fed`s mind. It was a case where the action was necessary if at all possible.

Lehman Brothers were in itself probably too big to fail in a sense that its failure had an enormous negative impact on the global financial system. Still, they were helpless because it was almost an insolvent firm. It did not have enough collateral to borrow from the Fed. The Fed could not put capital into an insolvent firm. It was before the TARP, or anything else had provided the capital that the Treasury could use, so the Fed just had no legal way to do it.

If the Fed could have avoided that, they would have done so. It was somewhat ad hoc, although the two cases in which the Fed intervened Bear Stearns and then AIG - the case was pretty straightforward, given not only the firms themselves but also the context and the environment that was going on at the same time.

Interestingly, the Fed had to get much more into this issue since the crisis, because there are several different rules and regulations which actually require the Fed and other regulatory agencies to make some determination about how systemically critical a firm is. For example, the new $\boldsymbol{B a}$ sel III capital requirements require the largest, most systemically critical firms to have a capital surcharge for them to have more capital than firms which are not as systemically critical. And as part of that process, the international bank regulators have worked together to try to set a set of criteria relating to size, complexity, interconnectedness, derivatives, a whole bunch of criteria that help determine how much extra capital they have to hold.

Likewise, the Fed, when it proves a merger of two banks, it has to evaluate whether the merger creates a systemically more dangerous situation. The Fed has worked hard, and they have put out a variety of criteria including some numerical thresholds that they look at to try to figure out if a merger creates a systemically critical firm. If it does, they are not supposed to allow that merger to happen. The science of doing this is progressing. It is still very in its infancy. But again, in the crisis, the Fed`s actual interventions were Bear Stearns and AIG along with other agencies. And they also assisted a couple of other institutions, but nothing nearly to the extent that the AIG situation involved.

However, the Fed is moving forward. It is looking very seriously at this, and indeed now the Fed has become much more focused on financial stability. They have a whole division of people working on a various matrix and various indicators both to try to identify risks to the system and also to try to identify firms that need to be particularly carefully supervised and may hold extra capital because of the potential risk that they bring to the system.

One vulnerability that was mentioned in the article was that the credit rating agencies were assigning AAA ratings to securities that carried much more risks than perhaps a AAA rating might want. It seems like the incentives would be aligned for the buyers to seek out more accurate ratings because they would be taking on more risk. Was there a systemic problem as far as how incentives were aligned within the credit rating system that allowed these faulty ratings to propagate throughout the system?

There were some incentive problems and one of them which is that instead of the seller of the security being the one who hires and pays the credit-rater. One would think that would be in the interest of the buyers who after all are the ones who are bearing the risk to band together somehow and pay the credit-rater to give them the best opinion they can about what the credit quality is of the security. Unfortunately, that model does not seem to work. The very few examples if any that the Fed knows of where it works, and the problem is what economists call the free-rider problem.

Basically, if five investors get together and pay Standard and Poor's to rate a particular issuance unless they can keep that completely secret, anybody else can find out what the rating was. Then they can take advantage of that without having to pay and having to be part of the consortium that pays. There have been a lot of ideas out there about how one can restructure the payment system to create better incentives for credit-raters. But it is a challenging problem because of an obvious solution of having the investors pay only works if the investors collectively can share the cost and somehow keep that information from being spread among other investors. 


\section{References}

Avdokushin, Y.F., Kovalenko, V.N. (2012). Perspektivy internatsionalizacii kitaiskogo ûanâ [The prospects of Chinese yuan's internationalisation]. Voprosy novoi ekonomiki, 2, 43-49.

Bernanke, B. (2015). The Courage to Act: A Memoir on a Crisis and its Aftermath. New York: W.W. Norton, 126-130.

Binder, A.I. (2013). Nekotorye aktual'nie aspekti transformacii ûanâ v mirovuû valûtu [Some critical aspects of transforming yuan into a world currency]. Den'gi i kredit, 11, 59-62.

Burlačkov, V.K. (2012). Reforma mirovoi valûtnoi sistemy i ispol'zovanie èkonomičeskogo invatianta [The reform of the world system of currencies and the use of economic invariant]. Voprosy èkonomiki, 1, 151.

Butorina, O.V. (2011). Valûtnye voiny. Kto zaplatit za preodolenie krizisa? [The currency wars. Who will pay for overcoming the crisis?]. Rossiâ v global'noi politike, 1(9), 165-178.

Goldberg, L.S., Cédric, T. (2008). Vehicle currency use in international trade. Journal of International Economics, 2(76), 177-192.

Griesgraber, J.M. (2009). Reforms for major new roles of the International Monetary Fund? The IMF Post-G-20 summit. Global Governance, 15(2), 179.

Jordà, Ò., Schularick, M., Taylor, A.M. (2011). Financial crises, credit booms, and external imbalances: 140 years of lessons. IMF Economic Review, 59(2), 340-378.

Kadayan, H. (2014). Indian rupee's role as an international currency. Abhinav - National Monthly Refereed Journal In Commerce \& Management, 2(3), 35-43.

Kasekende, L., Brixova, Z., Ndikumana, L. (2010). Africa: Africa's counter-cyclical policy responses to the crisis. Journal of Globalization and Development, 1, 1.

Kaufman, G.G. (2001). Emerging economies and international financial centers. Review of Pacific Basin Financial Markets and Policies, 4(4), 365-377.

Lane, P.R., Milesi-Ferretti, G.M. (2011). The cross-country incidence of the global crisis. IMF Economic Review, 2011, 59(1), 77-110.

Schindler, M. (2009). Measuring financial integration: A new data set. IMF Staff Papers, 1(56), 222-238.

Wade, R. (2008). The first world debt crisis of 2007-2010 in global perspective. Challenge, 51(4), 23-54.

Yu, Y. (2014). How far can renminbi internationalisation go? Asian Development Bank Institute's Working Paper, $461,9-15$.

Политика Центробанка РФ в условиях турбулентности на финансовых рынках

\section{Михаил Жариков}

Доктор экономических наук, доцент, профессор Департамента мировой экономики и мировых финансов, Финансовый университет, Москва, Россия

Аннотация. В статье рассматривается и сравнивается политика Центробанка РФ с деятельностью Федеральной резервной системы США в период интенсивной стадии глобального финансового кризиса 2008-2010 гг. Особое внимание акцентируется на функции ЦБ в качестве кредитора последней инстанции. Систематизированы наиболее значительные вопросы, которые необходимо учитывать при ликвидации последствий нынешнего экономического и финансового кризиса, вызванного коронавирусной инфекцией. Ключевые слова: центральный банк; кредитор последней инстанции; финансовый кризис; коронавирус; проблема банкротства крупных предприятий и организаций; правило Волкера; финансовое законодательство; секьюритизация; кредитные рейтинги 